Original Research Article

\title{
Evaluation of anti - inflammatory activity of aqueous extract of leaves of hibiscus sabdariffa in albino rats
}

\author{
Soumya B. Patil ${ }^{1 *}$, Swetha Munoli ${ }^{2}$
}

\begin{abstract}
${ }^{1}$ Department of Pharmacology, Navodaya Medical College, Hospital and Research Centre, Raichur, Karnataka, India ${ }^{2}$ Department of Pharmacology, ESIC-MC and PGIMSR, Rajaji nagar, Bangalore, Karnataka, India
\end{abstract}

Received: 21 February 2017 Accepted: 28 March 2017

*Correspondence to:

Dr. Soumya B. Patil,

Email: sou_doc@yahoo.co.in

Copyright: $\odot$ the author(s), publisher and licensee Medip Academy. This is an openaccess article distributed under the terms of the Creative Commons Attribution NonCommercial License, which permits unrestricted noncommercial use, distribution, and reproduction in any medium, provided the original work is properly cited.

\begin{abstract}
Background: Inflammation continues to be an area of great interest for research, probably due to the non-availability of a safer and more effective analgesic and anti-inflammatory agent. This has led to increase in demand for natural products with anti-inflammatory activity having fewer side effects. Nonsteroidal anti-inflammatory drugs (NSAIDs) such as indomethacin are used in the treatment of inflammation, fever and pain. However, NSAIDs cause gastric damage as a major adverse reaction. In this study, the anti-inflammatory activity of aqueous extract $H$. sabdariffa Linn was studied using carrageenan and formalin for acute and chronic inflammation respectively in albino rats.

Methods: In this study, anti-inflammatory activity of $H$. sabdariffa was studied and compared with standard drug, indomethacin. Aqueous extract of leaves of H. sabdariffa $(200 \mathrm{mg} / \mathrm{kg}$ or $400 \mathrm{mg} / \mathrm{kg})$ and indomethacin $(25 \mathrm{mg} / \mathrm{kg})$ were used to separate groups of rats and paw edema was measured by plethysmometer and compared with control group.
\end{abstract}

Results: $H$. sabdariffa did not show any significant reduction of paw edema ( $\mathrm{P}$ $>0.05$ ) in both the models of inflammation i.e. carrageenan induced acute model and formalin induced chronic model of inflammation.

Conclusions: $H$. sabdariffa didn't show any significant anti-inflammatory activity.

Keywords: Albino rats, Carrageenan, Edema, H. sabdariffa Linn, Formalin, Indomethacin

\section{INTRODUCTION}

Inflammation is an important physiological reaction, which occurs in response to a wide variety of injurious agents (bacterial infection or physical trauma) ultimately aiming to perform the dual function of limiting damage and promoting tissue repair. ${ }^{1}$ It requires the participation of various cell types expressing and reacting to diverse mediators along a very precise sequence. ${ }^{2}$ Although inflammation is beneficial in the setting of defence of the host against infectious invaders, if unchecked it can contribute to the pathogenesis of common chronic inflammatory diseases such as atherosclerosis, obesity induced insulin resistance, arthritis, inflammatory bowel disease and multiple sclerosis. ${ }^{3,4}$ Chronic inflammation begins 2-4 days after the onset of acute response and can last for weeks to months or years due to the persistence of the initiating stimulus, interference of the normal healing process, repeated bouts of acute inflammation or lowgrade smouldering due to continued production of immune response mediators. ${ }^{5}$

Inflammation and repair with fibrosis may be potentially harmful. Fibrosis may lead to disfiguring scars or fibrous bands that cause intestinal obstruction or tubal block leading to infertility or urethral stricture. For this reason, our pharmacies abound with anti- Inflammatory drugs, which ideally would control the harmful sequeal of inflammation yet not interfere with its beneficial effects. ${ }^{6}$

Many non-steroidal anti- inflammatory drugs (NSAID's) like aspirin, phenylbutazone, indomethacin etc. are in 
clinical use but, all these are not completely devoid of adverse effects. $^{7}$

Use of plant products is increasing in many segment of the population. ${ }^{8}$ At present, thousands of plant metabolites are being successfully used for the treatment of variety of diseases. According to an estimate, $80 \%$ of the world's population relied upon plants for their medication. ${ }^{9}$ Hibiscus is an important medicinal plant represented by 250 species. Hibiscus sabdariffa $L$. (Malvaceae), is an annual shrub and commonly used to make beverages. One study showed, the calyces have been used in folk medicines and claimed effective as diuretics, stomachic, aphrodisiac, antiseptic, astringent, cholagogue, digestive, sedative, laxative, antimicrobial or as remedy for pyrexia, abscesses, heart ailments and hypertension. ${ }^{10}$ Other studies say that $H$. sabdariffa $L$. possess biological activities like antihypertensive, anticancer, antihyperlipidemic, antioxidant, anticonvulsant, anxiogenic, CNS-depressant, serotoninergic activities, reducing oxidative liver damage, anti-inflammatory, and hypoglycemic activity. ${ }^{11-13}$ The antipyretic, analgesic and antiinflammatory activity of ethanol and aqueous extract of red calyces of $H$. sabdariffa has also been reported. ${ }^{14}$

The present study is therefore undertaken to evaluate the anti-inflammatory effect of aqueous extract of leaves of Hibiscus sabdariffa L. in albino rats.

\section{METHODS}

The study was carried out in the post graduate research laboratory, Department of Pharmacology, Navodaya Medical College, Raichur.

\section{Animals}

Animals used in the present experiment were albino rats weighing 150-250 g of either sex, obtained from National Institute of Nutrition, Hyderabad, maintained at air conditioned central animal house, Navodaya Medical College, Raichur under suitable conditions of housing, temperature, ventilation and nutrition as per CPCSEA guidelines. Ethical clearance from the Institutional Animal Ethical Committee was obtained. All the drugs were administered orally with the help of a sterile, nontoxic tube made up of polyvinyl chloride.

\section{Chemicals}

1. Carrageenan: The standard phlogestic agent Carrageenan (HiMedia Laboratories Pvt. Ltd.) as $1 \%$ suspension in normal saline was used to induce acute inflammation in the rat's right hind paw. Not more than $0.1 \mathrm{ml}$ was administered by the sub plantar route.

2. Indomethacin: It was obtained from Sun pharmaceuticals, New Delhi.
3. Formalin: This phlogestic agent Formalin (Entamology Lab, University of Agricultural Sciences, Raichur.) as $2 \%$ solution and was used to induce chronic inflammation in the rat's right hind paw. Not more than $0.1 \mathrm{ml}$ was administered by the sub plantar route.

\section{Preparation of extract}

The whole fresh leaves of Hibiscus sabdariffa were collected, air dried under shade for two days and then powdered. $100 \mathrm{~g}$ of powder was taken and kept for maceration for two days in $1000 \mathrm{ml}$ of distilled water, frequently stirred and about 5 to 10 drops of chloroform per day was added. Then it was filtered using a muslin cloth, so as to remove insoluble material. The filtrate was again filtered by double layered muslin cloth and then poured in ordinary, cleaned and already weighed plates for drying. Finally, the chocolate-colored semisolid residue was weighed and pooled together in an air and water proof container kept in a refrigerator at 40c. From this fresh preparation were made whenever required.

\section{Carageenan induced paw edema}

For acute inflammatory activity. This method is based on the plethysmometeric measurement of oedema produced by sub plantar injection of Carrageenan, in the hind paw of rat. Carrageenan is a mixture of polysaccharides composed of sulfated galactose units and is obtained from Irish Sea moss. Carrageenan was dissolved in normal saline and used in strength of $1 \%$.

\section{Digital plethysmometer}

The IITC 520 Plethysmometer was used to measure the paw volume. It consists of a water cell which is fitted on to a plexi glass stand. This water cell has an inlet in which the paw is dipped and an outlet with a stopcock. The water cell is connected to an electronic display which shows the volume of displacement of water in millilitre (ml) from the water cell when paw is dipped into water cell which is taken as paw volume. The paw is inserted into water, contained in a special water cell of which the resistance is changed due to the immersion of the animal's paw. This resistance change is calibrated in $\mathrm{ml}$ and displayed on the read out in $\mathrm{ml}$ with a resolution of $0.1 \mathrm{ml}$.

Acute inflammation was produced by sub plantar injection of $0.1 \mathrm{ml}$ of freshly prepared $1 \%$ suspension of Carrageenan in normal saline in the right hind paw of the rats and paw volume was measured plethysmometrically at $1 \mathrm{~h}, 2 \mathrm{~h}, 3 \mathrm{~h}$ and $4 \mathrm{~h}$ after Carrageenan injection. ${ }^{15}$

A line was marked at the level of the malleolus to facilitate the dipping of the foot up to the same mark every time. The hind foot of the animal was dipped up to the line marked on the foot into the water cell and the reading was recorded. The hind paw volume obtained at 
1h, 2h, $3 \mathrm{~h}$ and $4 \mathrm{~h}$ after Carrageenan injection both in control and test animals. By comparing the oedema produced in control rats and in those treated with drugs, percentage inhibition of oedema was calculated as follows.

Percentage inhibition $=\frac{\mathrm{Vc}-\mathrm{Vt}}{\mathrm{Vc}} \times 100$

Where,

$\mathrm{Vc}=$ Volume of paw oedema in control animals

$\mathrm{Vt}=$ Volume of paw oedema in treated animals.

\section{Procedure}

The drugs were administered orally with the help of a sterile, nontoxic tube made up of polyvinyl chloride which was introduced into the stomach of rat. Albino rats of either sex weighing between 150 and $250 \mathrm{~g}$ were used. 24 rats were selected and divided into 4 groups of 6 each.

- Group I: Control rats-received vehicle only (Distilled Water)

- Group II: Standard rats-received Indomethacin 25 $\mathrm{mg} / \mathrm{kg}$

- Group III: Test rats-received HS 200 mg/kg

- Group IV: Test rats-received HS 400 mg/kg.

\section{Formalin induced paw EDEMA}

For chronic inflammatory activity. This method is also based on the plethysmometeric measurement of oedema produced by injection of $0.1 \mathrm{ml}$ of $2 \%$ formalin into the sub-plantar area of hind paw of rat16. This method is one of the most suitable test procedures to screen anti arthritic and anti-inflammatory agents as it closely resembles human arthritis. ${ }^{17}$

\section{Procedure}

The drugs were administered orally with the help of a sterile, nontoxic tube made up of polyvinyl chloride which was introduced into the stomach of rat. Albino rats of either sex weighing between 150 and $250 \mathrm{~g}$ were used. 24 rats were selected and divided into 4 groups of 6 each.

- Group I: Control rats-received vehicle only (Distilled Water)

- Group II: Standard rats-received Indomethacin 25 $\mathrm{mg} / \mathrm{kg}$

- Group III: Test rats-received HS 200 mg/kg

- Group IV: Test rats-received HS 400 mg/kg.

All drugs were given orally one hour prior to formalin injection and continued for 7 consecutive days. During these seven days, the general behaviour was observed which did not reveal any significant change.

A line was marked at the level of the malleolus to facilitate the dipping of the foot up to the same mark every time. The hind foot of the animal was dipped up to the line marked on the foot into the water cell and the reading was recorded. The paw volume of animals was measured by digital Plethysmometer under anaesthesia on day-1 (immediately after injecting $0.1 \mathrm{ml}$ of $2 \%$ formalin into sub plantar aspect of right hind paw) and it was once again taken on day 7 .

The difference in paw volume on day 1 and day 7 is considered as inflammatory oedema. Volume changes in control group was compared with that of standard group and test group and the percentage inhibition of inflammation in test group or standard group is calculated by applying the formula:

Percentage inhibition $=\frac{\mathrm{Vc}-\mathrm{Vt}}{\mathrm{Vc}} \times 100$

Where,

$\mathrm{Vc}=$ Volume of paw oedema in control animals $\mathrm{Vt}=$ Volume of paw oedema in treated animals

\section{RESULTS}

\section{Carrageenan-induced EDEMA in rat hind paw}

The mean paw volumes at hourly interval in millilitre $(\mathrm{ml})$ of each group are represented in Table 1.

Table 1: Effect of aqueous extract of leaves of Hibiscus sabdariffa on carrageenan induced paw EDEMA in rats.

\begin{tabular}{|c|c|c|c|c|}
\hline \multirow{2}{*}{$\begin{array}{l}\text { Treatment } \\
\text { group (Dose) }\end{array}$} & \multicolumn{4}{|c|}{$\begin{array}{l}\text { Paw volume (edema) in } \mathrm{ml} \\
(\mathrm{mean} \pm \mathrm{SD})\end{array}$} \\
\hline & $1 \mathrm{hr}$ & $2 \mathrm{hr}$ & $3 \mathrm{hr}$ & $4 \mathrm{hr}$ \\
\hline $\begin{array}{l}\text { Control group } \\
\text { (D/W } 2 \mathrm{ml} / \mathrm{kg} \text { ) }\end{array}$ & $\begin{array}{l}1.20 \pm \\
0.10\end{array}$ & $\begin{array}{l}1.23 \pm \\
0.09\end{array}$ & $\begin{array}{l}1.27 \pm \\
0.09\end{array}$ & $\begin{array}{l}1.29 \\
\pm 0.09\end{array}$ \\
\hline $\begin{array}{l}\text { Group } 2 \\
\text { (IND } 25 \mathrm{mg} / \mathrm{kg} \text { ) }\end{array}$ & $1.24 \pm 0.08$ & $\begin{array}{l}1.21 \pm \\
0.09\end{array}$ & $\begin{array}{l}1.18 \pm \\
0.09\end{array}$ & $\begin{array}{l}1.16 \pm \\
0.09\end{array}$ \\
\hline $\begin{array}{l}\text { Group } 3 \\
\text { (HS } 200 \mathrm{mg} / \mathrm{kg} \text { ) }\end{array}$ & $1.16 \pm 0.62$ & $\begin{array}{l}1.19 \pm \\
0.06\end{array}$ & $\begin{array}{l}1.23 \\
\pm 0.06\end{array}$ & $\begin{array}{l}1.27 \\
\pm 0.06\end{array}$ \\
\hline $\begin{array}{l}\text { Group } 4 \\
\text { (HS } 400 \mathrm{mg} / \mathrm{kg} \text { ) }\end{array}$ & $1.15 \pm 0.12$ & $\begin{array}{l}1.19 \pm \\
0.11\end{array}$ & $\begin{array}{l}1.24 \\
\pm 0.10\end{array}$ & $\begin{array}{l}1.28 \pm \\
0.09\end{array}$ \\
\hline \multicolumn{5}{|c|}{ One-way ANOVA } \\
\hline F-value & 1.27 & 0.328 & 1.06 & 2.989 \\
\hline P-value & 0.309 & 0.805 & 0.387 & 0.06 \\
\hline \multicolumn{5}{|c|}{$\begin{array}{l}\text { Each value represents the mean } \pm \mathrm{SD}(\mathrm{N}=6) \text { df. Statistical } \\
\text { analysis by One-way ANOVA was done. } \mathrm{P} \text { value }<0.05 \text { is } \\
\text { significant; <0.001 is highly significant. Abbreviations: bw; } \\
\text { body weight, D/W; distilled water, IND; indomethacin, HS; } \\
\text { Hibiscus Sabdariffa }\end{array}$} \\
\hline
\end{tabular}

In control group and test groups there was a progressive increase in mean paw volume, where as in standard group there was progressive decrease in mean paw volume from $1 \mathrm{~h}$ to $4 \mathrm{~h}$. 


\section{Analysis of variance (ANOVA)}

Analysis of variance of paw volume (EDEMA) in $\mathrm{ml}$ at $1 \mathrm{~h}$

As shown in Table 1 application of ANOVA yielded $F$ ratio to be 1.27 and $\mathrm{P}$ value more than 0.05 which indicated a not significant difference in value of paw volume on comparing the rats treated with different doses of Hibiscus to control rats at $1 \mathrm{~h}$ of the treatment.

\section{Analysis of variance of paw volume (EDEMA) in $\mathrm{ml}$ at $2 \mathrm{~h}$}

As shown in Table 1 application of ANOVA yielded $F$ ratio to be 0.328 and $P$ value less than 0.05 which indicated that there was no significant difference in value of paw volume on comparing the rats treated with different doses of Hibiscus to control rats at $2 \mathrm{~h}$ of the treatment.

\section{Analysis of variance of paw volume (EDEMA) in $\mathrm{ml}$ at $3 \mathrm{~h}$}

As shown in Table 1 application of ANOVA yielded $F$ ratio to be 1.06 and $\mathrm{P}$ value more than 0.05 which indicated no significant difference in value of paw volume on comparing the rats treated with different doses of Hibiscus to control rats at $3 \mathrm{~h}$ of the treatment.

\section{Analysis of variance of paw volume (EDEMA) in $\mathrm{ml}$ at $4 \mathrm{~h}$}

As shown in Table 1 application of ANOVA yielded $F$ ratio to be 2.989 and $\mathrm{P}$ value more than 0.05 which indicated no significant difference in value of paw volume on comparing the rats treated with different doses of Hibiscus to control rats at $4 \mathrm{~h}$ of the treatment.

\section{Formalin-induced EDEMA in rats}

The mean paw volumes at 1 st day and 7 th day in millilitre (ml) of each group are represented in Table 2.

\section{Analysis of variance (ANOVA)}

Analysis of variance of paw volume (EDEMA) in $\mathrm{ml}$ at $1^{\text {st }}$ day

As shown in Table 2 application of ANOVA yielded $F$ ratio to be 1.000 and $P$ value more than 0.05 which indicated a not significant difference in value of paw volume on comparing the rats treated with different doses of Hibiscus to control rats at 1 st day of the treatment.

\section{Analysis of variance of paw volume (EDEMA) in $\mathrm{ml}$ at $7^{\text {th }}$ day}

As shown in Table 2 application of ANOVA yielded $F$ ratio to be 2.775 and $\mathrm{P}$ value more than 0.05 which indicated a not significant difference in value of paw volume on comparing the rats treated with different doses of Hibiscus to control rats at 7 th day of the treatment.
Table 2: Effect of aqueous extract of leaves of Hibiscus sabdariffa on formalin induced paw EDEMA in rats.

\begin{tabular}{|c|c|c|}
\hline \multirow[t]{2}{*}{ Treatment group (Dose) } & \multicolumn{2}{|c|}{$\begin{array}{l}\text { Paw volume (edema) in } \\
\mathrm{ml}(\text { mean } \pm \text { SD) }\end{array}$} \\
\hline & $\mathbf{1}^{\text {st }}$ day & $7^{\text {th }}$ day \\
\hline $\begin{array}{l}\text { Control group } \\
\text { (D/W } 2 \mathrm{ml} / \mathrm{kg} \text { ) }\end{array}$ & $1.38 \pm 0.05$ & $1.29 \pm 0.03$ \\
\hline $\begin{array}{l}\text { Group } 2 \\
\text { (IND } 25 \mathrm{mg} / \mathrm{kg} \text { ) }\end{array}$ & $1.34 \pm 0.09$ & $1.21 \pm 0.04$ \\
\hline $\begin{array}{l}\text { Group } 3 \\
\text { (HS } 200 \mathrm{mg} / \mathrm{kg} \text { ) }\end{array}$ & $1.32 \pm 0.07$ & $1.26 \pm 0.06$ \\
\hline $\begin{array}{l}\text { Group } 4 \\
\text { (HS } 400 \text { mg/kg) }\end{array}$ & $1.32 \pm 0.06$ & $1.27 \pm 0.05$ \\
\hline \multicolumn{3}{|l|}{ One-way ANOVA } \\
\hline F- value & 1.000 & 2.775 \\
\hline $\mathrm{P}$-value & 0.413 & 0.068 \\
\hline
\end{tabular}

Each value represents the mean $\pm \mathrm{SD}(\mathrm{N}=6)$. Statistical analysis by One-way ANOVA was done. $\mathrm{P}$ value $<0.05$ is significant; $<0.001$ is highly significant. Abbreviations: bw, body weight; D/W, distilled water; IND, indomethacin; HS, Hibiscus Sabdariffa

\section{DISCUSSION}

The objective of this study is to examine the antiinflammatory activity of aqueous extract of leaves of $H$. sabdariffa in albino rats. Models used for this study were

- Acute inflammation-carrageenan induced paw edema.

- Chronic inflammation-formalin induced paw edema.

The edema results from the action of inflammatory mediators such as histamine, serotonin, kinins and prostaglandins at the site of a local inflammatory insult. ${ }^{18}$

The early phase of edema, beginning from $1 \mathrm{~h}$ after administration of the irritant, is due to the release of histamine and serotonin, while the later phase, occurring from 3 to $5 \mathrm{~h}$ after administration of the irritants induced by bradykinin, protease, prostaglandin and lysosome. ${ }^{18,19}$

\section{CONCLUSION}

The conclusion of the present study in comparison with control and standard clearly indicate that the H. sabdariffa did not show any anti-inflammatory activity on paw EDEMA in acute and chronic inflammation induced by carrageenan and formalin, respectively.

This concluded that $H$. sabdariffa was devoid of any antiinflammatory activity is in correspondence to previous workers. $^{20}$

Funding: No funding sources Conflict of interest: None declared

Ethical approval: The study was approved by the Institutional Ethics Committee 


\section{REFERENCES}

1. Nathan C. Points of control in inflammation. Nature. 2002;420:846-52.

2. Gouwy M, Struyf S, Proost P, Van Damme J. Synergy in cytokine and chemokine network amplifies the inflammatory response. Cytokine Growth Factor Rev. 2005;16:561-80.

3. Wellen KE, Hotamisligil GS. Inflammation, stress and diabetes. J. Clin. Invest. 2005;115:1111-9.

4. Hanauer SB. Inflammatory bowel disease: epidemiology, pathogenesis and therapeutic opportunities. Inflamm. Bowel Dis. 2006;12:3-9.

5. Whicher J, Chambers R. Mechanisms in chronic inflammation. Immunol. Today. 1984;5:3-4.

6. Vinay K, Abdul KA, Nelson F, Aster JC. Robbins and Cotran's Pathologic basis of diseases. $8^{\text {th }}$ ed Philadelphia: Elsevier Publishers; 2010:43-77.

7. Laurence LB, Bruce AC, Björn CK. Goodman and Gilman's The pharmacological basis of therapeutics. $12^{\text {th }}$ ed China: McGraw-Hill Publishers; 2011.

8. Eisenberg DM, Kessler RC and Foster C. 1993. Unconventional Medicine in the United States: Prevalence, Costs and Patterns of Use. N Eng J Med. 328:246-52.

9. Rakh MS and Chaudhari SR. Evaluation of CNS depressant activity of Momordicadioica Roxb wild fruit pulp. Int. J. Pharm. Pharm. Sci. 2010;2(4):124-6.

10. Perry JM. Medicinal plants of East and Southeast Asia: attributed properties and Uses. MIT Press, Cambridge, MA. 1980;334-60.

11. Mahadevan N, Shivali and Kamboj P, Hibiscus sabdariffa L.-An Overview. Natural Product Radiance. 2009;8(1):77-83.

12. Chen CC, Hsu JD, Wang SF, Chiang HC, Yang MY, Kao ES et al. Hibiscus sabdariffa extract inhibits the development of atherosclerosis in cholesterolfed rabbits. J. Agri. Food Chem. 2003;51:5472-7.
13. Gosain SR, Ircchiaya PC, Sharma S. Thareja A. Kalra A. Hypolipidemic effect of ethanolic extract from the leaves Of Hibiscus sabdariffa L. in hyperlipidemic rats. Acta Poloniae PharmaceuticaDrug Research. 2010;67(2):179-84.

14. Reanmongkol W and Itharat A. Antipyretic activity of the extracts of Hibiscus sabdariffa calyces L. in experimental animals. Songklanakarin J. Sci. Technol. 2007;9:29-38.

15. Winter CA, Risley EA, Nuss CW. Carrageenaninduced oedema in hind paw of the rats-an assay for anti-inflammatory drugs. Proc Soc Exp Biol Med. 1962;111:544-7.

16. Chau TT. Analgesic testing in animal models. In: Pharmacological methods in the control of inflammation. Alan R Liss Inc. 1989:195-212.

17. Greenwald RA. Animal models for evaluation of arthritic drugs. Meth Find Clin Pharmacol. $1991 ; 13: 75-83$

18. Wallace JM. Nutritional and botanical modulation of the inflammatory cascade: eicosanoids, cyclooxygenase and lipoxygenase- as an adjunct in cancer therapy. Inegr Cancer Ther. 2002;1(1):7-37.

19. Harriot M, Marion E, Martha A, Wellford S, William A. Inflammation induced by histamine, serotonin, bradykinins and compound 48/480 in rat. Antagonist and mechanism of action. J Pharmacol Exp Therapeutics. 2004;191:300-2.

20. Dafallah, AA and al- Mustafa Z. Investigation of anti-inflammatory activity of Acacia nilotica and Hibiscus sabdariffa. Am. J. Chin. Med. 1996;24:2639.

Cite this article as: Patil SB, Munoli S. Evaluation of anti - inflammatory activity of aqueous extract of leaves of hibiscus sabdariffa in albino rats. Int $\mathbf{J}$ Basic Clin Pharmacol 2017;6:1155-9. 